\title{
Two-component signal-transducing systems involved in stress responses and vancomycin susceptibility in Lactobacillus sakei
}

\author{
Françoise Morel-Deville, ${ }^{1}+$ Franck Fauvel ${ }^{1}$ and Patrice Morel $^{2} \dagger$
}

\begin{abstract}
Author for correspondence: Françoise Morel-Deville. Tel: +334727286 02. Fax: +33472728600 . e-mail : Francoise.Morel-Deville@ens-lyon.fr
\end{abstract}

Laboratoire de Recherche sur la Viande ${ }^{1}$ and Laboratoire de Génétique Microbienne? , Institut National de la Recherche Agronomique, Domaine de Vilvert, 78352 Jouy-enJosas Cedex, France

\begin{abstract}
Fragments of five rrp genes encoding response regulators (RRs) in Lactobacillus sakei were amplified by PCR using degenerate oligonucleotide primers. The five rrp genes were part of distinct loci that also comprised hpk genes encoding histidine protein kinases (HPKs). The putative RRs belonged to the OmpR-PhoB subclass of response regulators that consist of $\mathbf{N}$-terminal receiver and C-terminal DNA-binding domains. The putative HPKs were members of the EnvZ-NarX family of orthodox histidine protein kinases which possess two transmembrane segments in a non-conserved $\mathbf{N}$-terminal domain and a C-terminal cytoplasmic kinase domain. Insertional inactivation of the rrp genes indicated that the RRs are implicated in susceptibility to the glycopeptide antibiotic vancomycin, and to extreme $\mathrm{pH}$, temperature and oxidative conditions.
\end{abstract}

Keywords: signal transduction, two-component systems, environmental stress, vancomycin, Lactobacillus sakei

\section{INTRODUCTION}

Lactobacillus sakei (previously Lactobacillus sake) is a lactic acid bacterium with major potential for use in biopreservation of meat and meat products. During storage of raw meat packaged under vacuum or in a modified atmosphere, $L$. sakei becomes the dominant population of the natural microflora and preserves the meat by lowering its $\mathrm{pH}$ through the production of lactic acid (for reviews see Stiles, 1996; Verplaetse, 1994). Moreover, bacteriocinogenic strains of $L$. sakei have been isolated with the ability to inhibit growth of spoilage and pathogenic micro-organisms such as Listeria monocytogenes, thereby ensuring safety and extending storage life of meat foods (Schillinger et al., 1991; Stiles \& Hastings, 1991). Therefore, as a means of controlling the manufacture of fermented meat products and of ensuring quality, starter and protective cultures of L. sakei are now used (Hammes \& Knauf, 1994; Verplaetse, 1994). However, the fermentation of carbohydrates to lactic acid, which decreases $\mathrm{pH}$, suppresses

+Present address: Laboratoire de Reproduction et Développement des Plantes, Ecole Normale Supérieure, 46 allée d'Italie, 69364 Lyon Cedex 07, France.

Abbreviations: 2CS, two-component system; HPK, histidine protein kinase; RR, response regulator; wt, wild-type. undesirable micro-organisms and accelerates changes in environmental conditions for subsequent ripening, is effective only provided that the added starter culture survives the heat treatment and the changes in osmotic conditions and concentrations of various metabolites (carbohydrates, nitrite oxide, organic and sorbic acids, hydrogen peroxide, carbon dioxide) involved in the packing processes. Although information about bacteriocin production and metabolic pathways of $L$. sakei are becoming available, the regulation of $L$. sakei physiology in connection with its practical application is still largely unknown.

It is likely that sensory and regulatory mechanisms operate in the bacteria during meat processing which enable them to monitor external conditions and respond accordingly, thus allowing them to compete and survive. Bacterial sensory devices often involve two-component regulatory systems (2CSs) i.e. histidine protein kinases (HPKs) and response regulators (RRs) (for reviews see Parkinson, 1993; Parkinson \& Kofoid, 1992; Stock et al., 1995). When exposed to the appropriate stimuli, the HPK is activated to autophosphorylate a specific histidine residue. The phosphorylated histidine serves as a high-energy intermediate and the phosphoryl group is subsequently transferred to an aspartic residue on the RR. Phosphorylation of the RR usually creates an active 
form of the protein, probably by causing conformational changes, which mediates the output response.

HPK and RR proteins contain conserved domains, termed transmitter and receiver domains, respectively. These are combined with input and output domains and can be arranged in different configurations to build specific signalling circuits (Alex \& Simon, 1994; Parkinson, 1993; Parkinson \& Kofoid, 1992).

Given the widespread occurrence of $2 \mathrm{CS}$ s throughout the bacterial kingdom as well as in eukaryotes (Alex \& Simon, 1994; Appleby et al., 1996; Chang \& Meyerowitz, 1994), the existence of HPKs and RRs in L. sakei was predicted. Therefore, we searched for representative members of the 2 CS family encoded by $L$. sakei genomic DNA. We have recently developed a random screening method to isolate RR-encoding genes from diverse bacteria (Morel-Deville et al., 1997). This method is based on PCR amplification using degenerate oligonucleotides with sequences derived from the conserved regions in the receiver domains of the RR family. In this article, we describe the PCR-based isolation and sequences of five unknown pairs of HPK/RR from $L$. sakei $23 \mathrm{~K}$, and analysis of the phenotypes resulting from mutations affecting the expression of each regulatory protein.

\section{METHODS}

Bacterial strains, media and plasmids. Escherichia coli strain TG1 $\left[\mathrm{F}^{\prime}\right.$ traD36 lacl $^{\mathrm{q}}-$ (lacZ)M15 proA $^{+} \mathrm{B}^{+} /$supE $\Delta($ hsdM-mcrB $) 5\left(\mathrm{r}_{\mathrm{K}}^{-} \mathrm{m}_{\mathrm{K}}^{-} \mathrm{McrB}^{-}\right)$thi $\Delta($ lac-proAB) ) (Sambrook et al., 1989) was used as a host for recombinant plasmids. $L$. sakei strain $23 \mathrm{~K}$ is a plasmidless derivative of meat-origin strain 23 (Berthier et al., 1996). Esch. coli and L. sakei cells were grown in Luria-Bertani broth (LB) at $37^{\circ} \mathrm{C}$ and in DeMan-Rogosa-Sharpe (MRS) medium supplemented with $0.5 \%$ glucose at $30^{\circ} \mathrm{C}$, respectively. Erythromycin $(150 \mu \mathrm{g}$ $\mathrm{ml}^{-1}$ for Esch. coli and $5 \mu \mathrm{g} \mathrm{ml}^{-1}$ for L. sakei), or ampicillin $\left(100 \mu \mathrm{g} \mathrm{ml}^{-1}\right)$ were added as required. The MIC of vancomycin was determined with the Etest system (AB Biodisk). Approximately $10^{5}$ cells in exponential-growth phase were plated onto MRS agar medium and the MIC was read after $18-48 \mathrm{~h}$ incubation.

Plasmid constructions are based on the phagemid pBluescript $\mathrm{SK}^{+}$(Stratagene) or the suicide vector $\mathrm{pRV300,} \mathrm{a} \mathrm{pBluescript}$ $\mathrm{SK}^{+}$derivative conferring erythromycin resistance (Leloup et al., 1997).

Standard DNA procedures. Restriction enzymes, ligase and polymerase were used according to the suppliers' recommendations. Molecular cloning, chromosomal and plasmid DNA extractions, restriction analyses and electrotransformation of Esch. coli and L. sakei were performed according to published methods (Anderson \& Mc Kay, 1983; Berthier et al., 1996; Sambrook et al., 1989). For sequencing purposes, plasmid DNA was prepared as described by Sorokin et al. (1995) and PCR fragments were purified using the Promega Wizard PCR Preps DNA purification system.

Synthetic oligonucleotides and PCR techniques. Singlestranded DNA oligonucleotide primers were synthesized on a Beckman Oligo 1000 DNA Synthesizer. PCR reagents were purchased from Boehringer Mannheim and used according to the manufacturer's instructions using a Perkin-Elmer Cetus 9600 Thermal Cycler.

The design of the degenerate DD and K primers (384- and 256fold degeneracy, respectively), the PCR amplification using these primers and the cloning of the PCR products (approx. 290 bp) were described previously (Morel-Deville et al., 1997). The DD and $K$ primers are complementary to conserved amino acid stretches in the DD and the $K$ boxes of the receiver modules of bacterial RRs (Parkinson, 1993).

For inverse PCR, total DNA digested with restriction enzymes was diluted to a concentration of $4-10 \mu \mathrm{g} \mathrm{ml}^{-1}$, ligated for $16 \mathrm{~h}$ at $16{ }^{\circ} \mathrm{C}$, precipitated and amplified using the Boehringer ExpandTM Long template PCR system.

Southern blot analysis. After agarose gel electrophoresis, $L$. sakei $23 \mathrm{~K}$ chromosomal DNA was transferred onto a Hybond$\mathrm{N}$ nylon membrane (Amersham) in a vacuum blotter system (Bio-Rad). Selection was achieved by hybridization under stringent conditions with ${ }^{32} \mathrm{P}$-labelled probes generated from the $\sim 290 \mathrm{bp}$ PCR fragments containing rrp internal sequences.

Mini-library construction and cloning of rrp genes. L. sakei $23 \mathrm{~K}$ genomic DNA was digested with HindIII, and fragments of approximately $3.6 \mathrm{~kb}$ were purified and ligated to an HindIII-linearized pBluescript $\mathrm{SK}^{+}$vector. This mini-library was used to transform Esch. coli TG1 cells, then ampicillinresistant transformants were tested by colony hybridization (Sambrook et al., 1989) using a rrp-1-specific probe. A similar approach was used for the other libraries, which were constructed from 3.0 and $3.2 \mathrm{~kb} \mathrm{ClaI}$, and 2.3 and $3.5 \mathrm{~kb} \mathrm{SspI}$ genomic DNA fragments suspected to contain the $r r p-2$, $r r p$ $48, \operatorname{rrp}-3$ or $r r p-31$ genes, respectively.

DNA sequencing. Nucleotide sequence determination was performed using the Applied Biosystems PRISM Direct, Reverse and Dye Terminator Sequencing Kits on the PerkinElmer Cetus 9600 Thermal Cycler or the Applied Biosystems Catalyst Station. Sequencing was performed either directly on the products obtained by inverse PCR or on plasmid DNA after cloning in a pBluescript $\mathrm{SK}^{+}$vector. The XBAP program (Dear \& Staden, 1991) was used for fragment assembly. The Genetic Computer Group (GCG) package (Devereux et al., 1984) was used for nucleotide and amino acid sequence analysis and for homology searches. Transmembrane domains were predicted using the Helical Transmembrane Region program (Rost et al., 1995).

Disruption of the rrp genes. Chomosomally interrupted rrp mutants were constructed according to Leloup et al. (1997). Briefly, internal fragments of $r r p$ genes were amplified by PCR using $L$. sakei $23 \mathrm{~K}$ genomic DNA as template and specific primers (positions 29-617 for $r r p-1,47-682$ for $r r p-2,14-526$ for $r r p-3,31-654$ for $r r p-31$ and 51-711 for $r r p-48$ ) (see Fig. 2). The amplified fragments were purified and cloned into the vector $\mathrm{pRV} 300$ which confers erythromycin resistance in Esch. coli and $L$. sakei but cannot replicate autonomously in $L$. sakei. The recombinant plasmids were introduced into Esch. coli by transformation and the presence of the inserts was confirmed by DNA sequencing. The plasmids were introduced into $L$. sakei strain $23 \mathrm{~K}$ by electroporation, transformants were selected on erythromycin and analysed by Southern blot hybridization. The $r r p-1-, r r p-2-, r r p-3-, r r p-31$ - and $r r p-48-$ disrupted mutants were named RVRR1, RVRR2, RVRR3, RVRR31 and RVRR48, respectively.

Effect of hydrogen peroxide, acid $\mathrm{pH}$ and heat on cell viability. For growth patterns at different temperatures or for 
Table 1. ORF features

\begin{tabular}{|c|c|c|c|c|c|c|c|c|}
\hline ORF & $\begin{array}{c}\text { GenBank } \\
\text { entry }\end{array}$ & $\begin{array}{l}\text { Endpoints } \\
\qquad(\mathbf{b p})^{*}\end{array}$ & $\begin{array}{l}\text { Size } \\
\text { (aa) }\end{array}$ & $\begin{array}{c}\text { Translation } \\
\text { start } \dagger\end{array}$ & $\begin{array}{l}\text { SWISS- } \\
\text { PROT } \\
\text { entry }\end{array}$ & Description & $\begin{array}{l}\text { FASTA } \\
\text { score }\end{array}$ & $\begin{array}{l}\text { Percentage } \\
\text { match } \\
\text { (no. of aa) }\end{array}$ \\
\hline orf $B$ & AF036964 & $1218-1 \neq$ & 406 & $\begin{array}{l}\text { tgggGGAGGtc } \\
\text { gctacaATG }\end{array}$ & P42424 & $\begin{array}{l}\text { Accessory protein } \mathrm{YxdM} \\
\text { (B. subtilis) }\end{array}$ & 205 & $\begin{array}{r}26.9 \% \\
(372)\end{array}$ \\
\hline $\operatorname{orf} A$ & AF036964 & $1972-1199$ & 258 & $\begin{array}{l}\text { attcgGGAGtgt } \\
\text { gacaaaATG }\end{array}$ & P42423 & $\begin{array}{l}\text { ABC transporter } \mathrm{YxdL} \\
\text { (B. subtilis) }\end{array}$ & 791 & $\begin{array}{r}48.6 \% \\
(245)\end{array}$ \\
\hline$r r p-1$ & AF036964 & $2112-2783$ & 224 & $\begin{array}{l}\text { gtctgAGGAGc } \\
\text { gcttattATG }\end{array}$ & P42421 & $\begin{array}{l}\text { Hypothetical RR protein YxdJ } \\
\text { (B. subtilis) }\end{array}$ & 649 & $\begin{array}{r}44 \cdot 4 \% \\
(224)\end{array}$ \\
\hline$h p k-1$ & AF036964 & $2796-3812$ & 339 & $\begin{array}{l}\text { attccataAGGA } \\
\text { GtaattATG }\end{array}$ & P42422 & $\begin{array}{l}\text { Hypothetical HK protein YxdK } \\
\text { (B. subtilis) }\end{array}$ & 487 & $\begin{array}{r}39 \cdot 2 \% \\
(194)\end{array}$ \\
\hline orfC & AF036965 & $375-1505$ & 377 & $\begin{array}{l}\text { ggttGGAGGGt } \\
\text { ttatttaATG }\end{array}$ & & No homologies & & \\
\hline$r r p-2$ & AF036965 & $1528-2238$ & 237 & $\begin{array}{l}\text { gaGAAGGAtg } \\
\text { acattgATG }\end{array}$ & P13792 & $\begin{array}{l}\text { Alkaline phosphatase synthesis } \\
\text { transcriptional regulator PhoP } \\
\text { (B. subtilis) }\end{array}$ & 688 & $\begin{array}{r}52 \cdot 0 \% \\
(237)\end{array}$ \\
\hline$b p k-2$ & AF036965 & 2228-3684‡ & 486 & $\begin{array}{l}\text { attaGAGGAtcc } \\
\text { cgcacATG }\end{array}$ & P23545 & $\begin{array}{l}\text { Alkaline phosphatase synthesis } \\
\text { sensor protein PhoR (B. subtilis) }\end{array}$ & 447 & $\begin{array}{r}31 \cdot 1 \% \\
(270)\end{array}$ \\
\hline$r r p-3$ & AF036966 & $218-928$ & 237 & $\begin{array}{l}\text { caAGGAGGAt } \\
\text { actaaaATG }\end{array}$ & P13792 & $\begin{array}{l}\text { Alkaline phosphatase synthesis } \\
\text { transcriptional regulator PhoP } \\
\text { (B. subtilis) }\end{array}$ & 667 & $\begin{array}{r}54 \cdot 7 \% \\
(236)\end{array}$ \\
\hline$h p k-3$ & AF036966 & $941-2836$ & 632 & $\begin{array}{l}\text { cAGGAGtaagtt } \\
\text { taacgcATG }\end{array}$ & P23545 & $\begin{array}{l}\text { Alkaline phosphatase synthesis } \\
\text { sensor protein PhoR (B. subtilis) }\end{array}$ & 357 & $\begin{array}{r}35 \cdot 4 \% \\
(240)\end{array}$ \\
\hline $\operatorname{rrp}-31$ & AF036967 & $255-938$ & 228 & $\begin{array}{l}\text { aattaaatGAGG } \\
\text { taattaatATG }\end{array}$ & Q06239 & $\begin{array}{l}\text { Transcriptional activator VanR } \\
\text { (Ent. faecium) }\end{array}$ & 617 & $\begin{array}{r}43.7 \% \\
(228)\end{array}$ \\
\hline$b p k-31$ & AF036967 & $941-2137$ & 399 & $\begin{array}{l}\text { gatataaggtcGA } \\
\text { GGtctaATG }\end{array}$ & Q06240 & $\begin{array}{l}\text { Vancomycin resistance protein } \\
\text { VanS (Ent. faecium) }\end{array}$ & 507 & $\begin{array}{r}37 \cdot 2 \% \\
(218)\end{array}$ \\
\hline $\operatorname{rrp}-48$ & AF036968 & $379-1116$ & 246 & $\begin{array}{l}\text { aaagaGAAGG } \\
\text { AattctaATG }\end{array}$ & P13792 & $\begin{array}{l}\text { Alkaline phosphatase synthesis } \\
\text { transcriptional regulator PhoP } \\
\text { (B. subtilis) }\end{array}$ & 492 & $\begin{array}{r}41 \cdot 0 \% \\
(246)\end{array}$ \\
\hline$h p k-48$ & AF036968 & $1119-2552$ & 478 & $\begin{array}{r}\text { attcagcggtcaat } \\
\text { aaacactaATG }\end{array}$ & P23545 & $\begin{array}{l}\text { Alkaline phosphatase synthesis } \\
\text { sensor protein PhoR (B. subtilis) }\end{array}$ & 375 & $\begin{array}{r}34 \cdot 2 \% \\
(219)\end{array}$ \\
\hline
\end{tabular}

"In the corresponding GenBank entry.

† Putative start codons are indicated by bold letters and nucleotides complementary to 16S RNA (Mercenier et al., 1994) are indicated by upper-case letters.

$\ddagger$ Partial sequence.

aerated growth, MRS was inoculated with an overnight $L$. sakei culture $\left(10^{6}\right.$ cells $\left.\mathrm{ml}^{-1}\right)$, grown at $30^{\circ} \mathrm{C}$ without shaking to an $\mathrm{OD}_{600}$ of 0.3 , and incubation was continued under various temperature and aeration conditions.

For sensitivity to $\mathrm{H}_{2} \mathrm{O}_{2}$ and heat-killing, bacterial cultures were grown at $30^{\circ} \mathrm{C}$ in $\mathrm{MRS}$ to an $\mathrm{OD}_{600}$ of $\sim 0.3$ and incubated either in the presence of $2 \mathrm{mM} \mathrm{H}_{2} \mathrm{O}_{2}$ at $30^{\circ} \mathrm{C}$ or at $55^{\circ} \mathrm{C}$ for the indicated times. Appropriate cell dilutions were plated on MRS agar and viable cells were scored as c.f.u. at $30^{\circ} \mathrm{C}$. Survival of mutants was expressed as the number of input cells which retained viability relative to that of the wildtype (wt) strain. For growth in acid $\mathrm{pH}$ conditions, exponential-phase cell suspensions were washed twice in $0.9 \%$ $\mathrm{NaCl}$, appropriate dilutions were plated onto MRS agar medium without acetate and the initial $\mathrm{pH}$ was reduced to 5.5 with MOPS. Growth under these conditions was accompanied by a rapid decrease in $\mathrm{pH}$, reaching a value of about 3.5 after $24 \mathrm{~h}$ incubation at the surface of a plate saturated with colonies whereas it was usually maintained above 4.1 in normal MRS medium. Initial inocula of stationary-phase cell suspensions were also transferred onto MRS medium at pH 3.0 from $30 \mathrm{~min}$ to $5 \mathrm{~h}$ and viable cells were scored as c.f.u.

\section{RESULTS}

\section{PCR amplification of genes encoding response regulators from $L$. sakei $23 \mathrm{~K}$}

The degenerate primers previously designed to amplify fragments of genes encoding RRs from a wide range of bacteria (Morel-Deville et al., 1997) were used to isolate RR genes from L. sakei $23 \mathrm{~K}$ genomic DNA. Five different RR DNA sequences were obtained from a total of 82 independent PCR fragments analysed. The corresponding genes, designated $r r p-1, r r p-2, r r p-3, r r p-31$ and $r r p-$ 48 , were detected in $6,56,12,2$ and 1 clones, respectively. The deduced amino acid sequence of the five segments of the rrp genes, the size of which ranged from 279 to $288 \mathrm{bp}$, displayed striking amino acid similarities with 

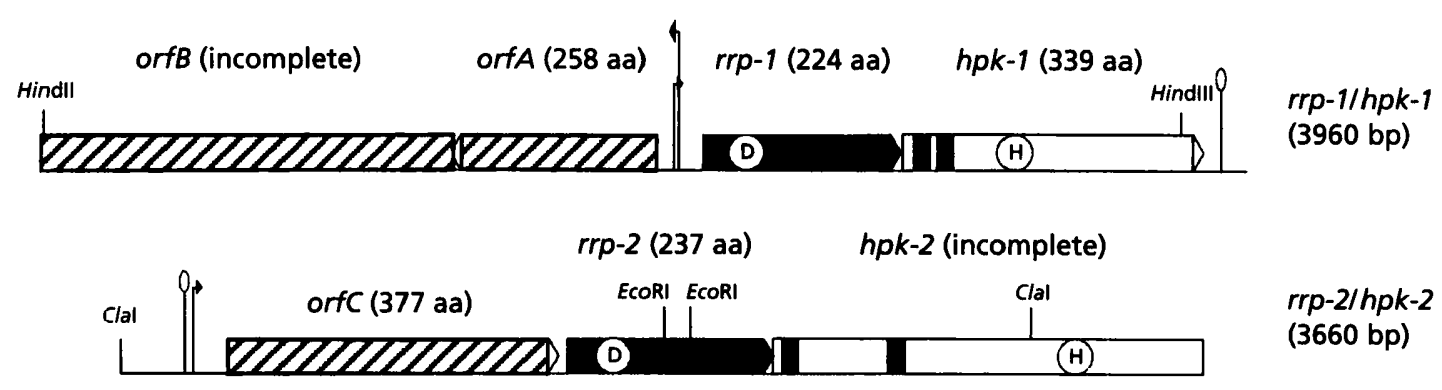

rrp-2/hpk-2

(3660 bp)

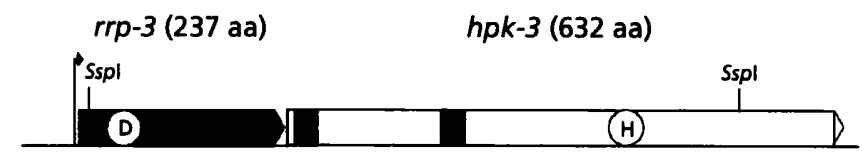

rrp-3/hpk-3

(2860 bp)

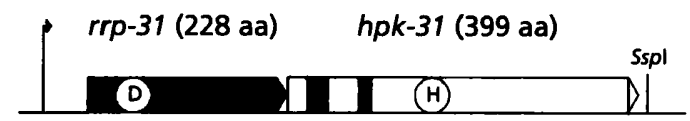

rrp-31/hpk-31

(2280 bp)

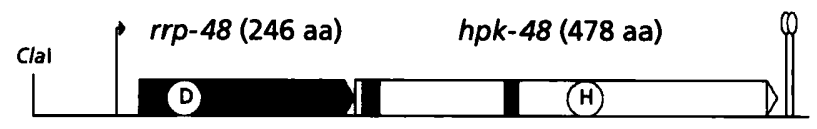

rrp-48/hpk-48

(2640 bp)

$1 \mathrm{~kb}$

Fig. 1. Schematic representation of the five two-component signal-transducer genes from $L$. sakei $23 K$. The RR-encoding genes are indicated by black bars, the HPK-encoding genes by white bars and the other putative ORFs by hatched bars. The positions of the putative promoters and terminators are indicated. The sizes of the deduced proteins are given in parentheses. The positions of the conserved aspartate (D) and histidine (H) residues are shown. The putative transmembrane regions are indicated by black rectangles.

the consensus sequence of receiver modules of RRs (Pao \& Saier, 1995; Volz, 1995), indicating that random PCR-mediated cloning of RR genes was successful in $L$. sakei.

\section{Cloning and sequencing of five $L$. sakei $23 K$ response regulator genes}

The five cloned fragments of the rrp genes were used as probes for Southern blot analysis of several restriction digests of L. sakei $23 \mathrm{~K}$ chromosomal DNA. Minilibraries were constructed and approximately 500 clones were screened for each library by colony hybridization. The $r r p-1$ and $r r p-3$ genes were cloned on a $3.6 \mathrm{~kb}$ HindIII and a $2.3 \mathrm{~kb} S s p$ I fragment, respectively, and their complete sequence determined (Table 1). The rrp2, $r r p-31$ and $r r p-48$ genes could not be cloned using this approach and their sequences were determined by inverse PCR (Table 1).

\section{Nucleotide sequence analysis of five $L$. sakei $23 \mathrm{~K}$ two-component regulatory systems}

HPKs and RRs are frequently organized as an operon (Parkinson, 1993; Stock et al., 1995). It was therefore expected that sequencing the regions surrounding the five putative RR-encoding genes would reveal genes encoding cognate HPKs.
In the five chromosomal regions sequenced, we found by using the FASTA program (Pearson \& Lipman, 1988) 10 ORFs, rrp-1, rrp-2, rrp-3, rrp-31 and $r r p-48$, and $b p k-1$, incomplete $h p k-2, h p k-3, h p k-31$ and $h p k-48$, whose translation products show significant similarities to RRs and HPKs in the sequence databases (Fig. 1, Table 1). Three other ORFs (orf $A$, incomplete orf $B$ and orf $C$ ) with no homology to 2 CSs have also been found (Fig. 1, Table 1).

In each region, the $h p k$ gene is adjacent to the $r r p$ gene (Fig. 1), and is located either immediately downstream of the $r r p$ gene (for $r r p-1 / h p k-1, r r p-3 / h p k-3, r r p-$ $31 / h p k-31$ and $r r p-48 / h p k-48$ ) or overlapping it (for $r r p-2 / h p k-2)$, showing that gene clustering is indeed present in $L$. sakei 2 CSs.

\section{Structural features of the deduced amino acid sequences}

To gain insight into the features of the L. sakei putative Rrp/Hpk proteins identified in this study, we conducted a series of computer-aided analyses of their deduced amino acid sequences.

(i) Response regulators. The five $L$. sakei $r r p$ products are composed of a $\mathrm{N}$-terminal receiver module of approximately 125 amino acids attached via a linker sequence to 
(a)

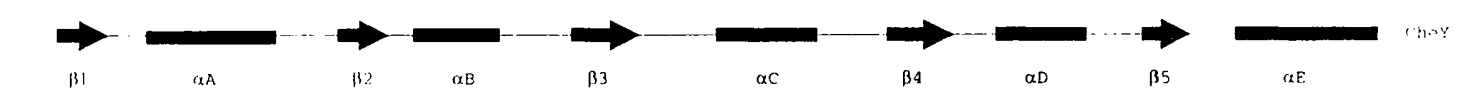

MFEIMIVEDUPT IANLIAENLEKWQLKAI I PDDFDT IFDRFLTDKP. . HLVLLDINLPVYDGF YWCRKIREVS . KVPI IFISSRSTNMDMVMSMNMGGDDFVNKPFSMEVLIAK INALLR RTP - 1 TLMKTILVVDDEPAILTLLRYNLEOEHFKVMTATDGAQALTMALOQK.F. DF I I LDLMLPKLDG I AVTKKIREAKLKTP IMILTAKDNETDKIVGLEVGADDYVTKPFSPREI IAR IRA IER RRP - 2 MAKKILVVDDEKPISDIVKFNLTKEGYDVYTAYDGEEALQOVEEVV. P. DL ILLDLMLPKVDGLEVARQVRKSHDM. PI IMVTAKDSEIDKVIGLELGADDYVTKPFSNRELVARVKANLR RIP - 3 MK ILIVDDDKEIVELLSIYVKNEGYEPIQAFTGKEALTKIATNP. GIDLMILDIMMPNMSG I EVIKAVRKDS. QVPILVVSAKTTDMDKIQGLITGADDYVSKPFNPLEVMARVKSLLR RRP - 31 MKILMVEDNKSVSEMMGMFFQKEAWDAHFAYDGNEAVEQFSVDPDSWDI ITLDLNLPGMDGMVVAKIREQSKVVPIIMLTARDSESDQVLGLELGADDYVTKPFSPITLIARIKALHR RYP - 48 MNKK I LVVDDEES IVTLLQYN ERSGYDVITASDGEEALKKAETEK. P. DLIVLDVMLPKLDG I EVCKQLRQQKLMT? ILMLTAKDEEFDKVLGLELGADDYMTKPFSPREVNARVKAILR PhOP MSDK I LI VDDEHEI ADLVELYLKNENYTVFKYYTAKEALECI DKSE. I IDLA ILDIMLPGTSGLTICQKIRDKH : TYPI IMLTTKDTEVDKITGLT IGADDY ITKPFRPLELIARVKAQLR VANR

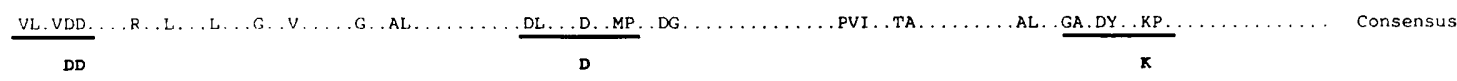

(b)

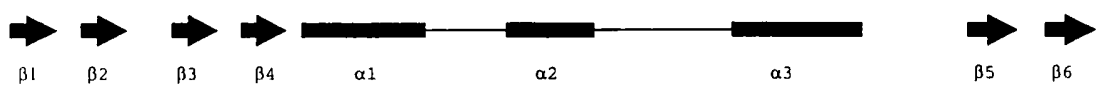

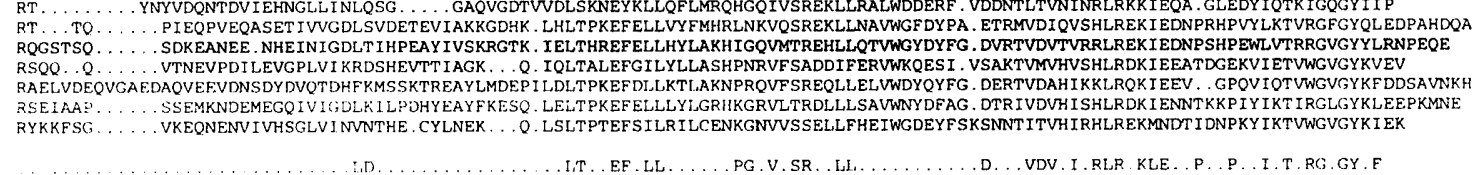

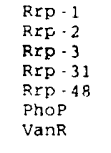

Fig. 2. Multiple sequence alignments of the deduced $\mathrm{N}$-terminal (a) and C-terminal (b) domains of the five RRs from $L$. sakei $23 \mathrm{~K}$ with those of $B$. subtilis PhoP and Ent. faecium VanR. The fully conserved aspartate is indicated by an asterisk, and conserved motifs present within members of the RR family, designated DD, D and K, are specified by lines below the corresponding sequences (a). Consensus amino acid residues found in the receiver domain of RRs (a), and those found in the $\sigma^{70}$-dependent DNA-binding domain of class 2 RRs (b), are indicated (Pao \& Saier, 1995). The secondary structure of the Esch. coli CheY (Stock et al., 1989) (a), and those of the C-terminal DNA-binding domain of Esch. coli OmpR (Martinez-Hackert \& Stock, 1997) (b), are depicted schematically above the multiple alignment, with arrows corresponding to $\beta$-strands, bars to $\alpha$-helices and lines to loop regions. In the C-terminal DNA-binding domain (b), the presumed helix-turn-helix DNA-binding motif, with the loop between $\alpha 2$ and $\alpha 3$, is thought to be involved in RNA polymerase interaction, and helix $\alpha 3$, consisting of 12 amino acids, is presumably involved in DNA recognition (Mizuno \& Tanaka, 1997). The latter sequence contains hydrophobic residues at positions $1,5,8$ and 12 , well-conserved among the OmpR subfamily, and variable residues at positions 3, 6 and 10, thought to recognize specific target DNA (Mizuno \& Tanaka, 1997). Numbers on the left refer to the amino acid positions in the corresponding proteins indicated on the right.

a C-terminal effector domain (Pao \& Saier, 1995). As shown in Fig. 2(a), the predicted N-terminal sequences of the L. sakei Rrp proteins can be aligned with the secondary structure of the chemotaxis RR CheY (Stock et al., 1989) on the basis of residues that correspond to the hydrophobic core with five repeating units of the general form 'turn-strand-turn-helix'. They contain most of the highly conserved residues found in the consensus sequence (Pao \& Saier, 1995; Parkinson, 1993), i.e. the $\mathrm{N}$-terminal DD box, the invariant aspartate residue ( $\mathrm{D}$ box) close to the centre and the Cterminal $\mathrm{K}$ box (Fig. 2a).

Alignment of the C-terminal end of the five lactobacillus proteins revealed that striking sequence similarities extend throughout their entire effector domain with DNA-binding domains found in $\sigma^{70}$-dependent class 2 proteins, the so-called OmpR-PhoB subfamily of bacterial RRs (Pao \& Saier, 1995; Parkinson \& Kofoid, 1992) (Fig. 2b). They all possess the succession of $\beta$ strand segments and $\alpha$-helices characterized by X-ray crystallography of the Esch. coli OmpR C-terminal DNA-binding domain (Martinez-Hackert \& Stock, 1997), in particular the presence of presumed sites for DNA recognition and RNA polymerase interaction (Mizuno \& Tanaka, 1997) (Fig. 2b).
Greatest sequence similarity was observed with the Bacillus subtilis regulator of the phosphate assimilation pathway PhoP (Seki et al., 1987), the uncharacterized YxdJ (Yoshida et al., 1994) and the Enterococcus faecium vancomycin regulator VanR (Arthur et al., 1992), all of which are members of the same OmpRPhoB subfamily (Table 1 ). From these results, it is reasonable to assume that the five $L$. sakei putative Rrp proteins belong to this subfamily of RRs and may also be DNA-binding regulatory proteins.

(ii) Histidine kinases. The five $L$. sakei $\mathrm{Hpk}$ proteins present strong sequence similarities with members of the EnvZ-NarX family of orthodox HPKs that contain a typical C-terminal transmitter domain of approximately 240 amino acids determining the HPK activity in which the autophosphorylated histidine residue is situated (Parkinson \& Kofoid, 1992; Stock et al., 1995) (Table 1).

Fig. 3(a) illustrates the amino acid sequences of the Cterminal domains of Hpk-3, Hpk-31 and Hpk-48. Similarly to B. subtilis PhoR (Seki et al., 1988) and Ent. faecium VanS (Arthur et al., 1992), they possess the five conserved HPK motifs (H, N, G1, F/D and G2 boxes). Truncated Hpk-2 exhibits only two of the five HPK motifs ( $\mathrm{H}$ and $\mathrm{N}$ boxes) but it seems to belong to the same HPK subfamily (Table 1, Fig. 3a). Hpk-1 exhibits 
(a)

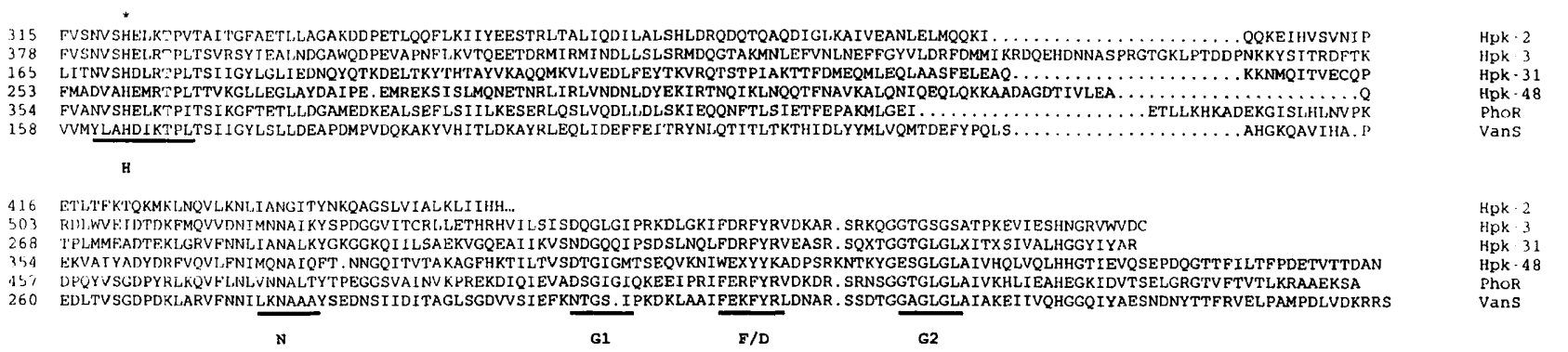

(b)

YMNOWVHQVKT PLSV I NLI I IQEEDEPV . . . . FEQI KKEVRQI EFGLETLLY SSRLDLFERDFKIEAVSLSELLQSVIQSYKRFF IQYRVY PKMNVCDDHQIYTDAKWLK

ILNQIVSNALKYTP. QNGQITIDLAHDEQGVWLSVSDSGIG I PAEDLPRVFDKGFTGQNGRQSNQRSTGLGLYLAKSLSNKLGHATLCQLNARKWCDFQITLYLFKLL AIGQVVTNAVKY SAGKSDRLELNVFCDEDRTVLEVKDYGVGI PSQDI KRVFDPYYTGENGRRF. QESTGIGLHLVKEITDKLNHTVDISSSPGEGTSVRFS. FLTKM (D)

Fig. 3. Multiple sequence alignments of the deduced C-terminal domains of Hpk-2, Hpk-3, Hpk-31 and Hpk-48 with those of $B$. subtilis PhoP and Ent. faecium VanS (a), and sequence alignments of the deduced C-terminal domain of Hpk-1 with that of $B$. subtilis $Y x d K(b)$. The fully conserved histidine is indicated by an asterisk, and conserved motifs present within members of the HPK family, designated $H, N, G 1, F / D$ and $G 2$ are indicated by lines below the corresponding sequences. The $\mathrm{H}$ box is the presumed autophosphorylation site, in which the conserved histidine is phosphorylated upon signal detection; the phenylalanine/aspartate (F/D) and glycine (G1 and G2) boxes are thought to be involved in nucleotide binding, and the asparagine $(N)$ box is of unknown function (Stock et al., 1995). Numbers on the left refer to the amino acid positions in the corresponding proteins indicated on the right. Although only partially sequenced, Hpk-2 shares extensive similarities with sequences surrounding the known conserved histidine residue. Hpk-1 is somewhat different from the other $L$. sakei kinases and more similar to the B. subtilis HPK YxdK (b). Hpk-1 exhibits sequence differences in the $H, N, F / D$ and $G 2$ boxes: it has only one of the conserved asparagine residues, lacks a conserved aspartate region and does not contain a typical glycine-rich G2 region. Such differences in the HPK transmitter domain are also observed in the B. subtilis YxdK and may correspond to a subdivision into a separate subfamily.

sequence differences in the $\mathrm{H}, \mathrm{N}, \mathrm{F} / \mathrm{D}$ and $\mathrm{G} 2$ boxes and is more similar to the B. subtilis HPK YxdK (Fig. 3b).

Stretches of hydrophobic residues that probably represent transmembrane regions were identified in the $\mathrm{N}$ terminal part of the sequences, suggesting that the five lactobacilli Hpk proteins are membrane-associated, with a $\mathrm{N}$-terminal environmental signal-sensing domain residing in the extracellular space and a C-terminal domain in the cytoplasm (Fig. 1). With regard to the amino acid sequence and length, the $\mathrm{N}$-terminal portion of the five $L$. sakei putative kinases are all different. Furthermore, they show no homology to any of the known HPK sequences (data not shown). Since the Nterminal domain of HPK is the presumed signal-input domain that contains the sensory receptor, these data suggest novel properties for each of the Hpk proteins.

\section{Insertional inactivation of the rrp coding sequences}

To obtain clues as to the physiological functions of the 2CSs isolated in this study, $r r p$ mutants of $L$. sakei $23 \mathrm{~K}$ were constructed by gene disruption. The frequency of $r r p-31$ gene inactivation was considerably lower than that observed for the four other genes [only one transformant ( $\mu$ g plasmid DNA $)^{-1}$ was obtained compared to 30-90 transformants ( $\mu$ g plasmid DNA) ${ }^{-1}$ with the other mutants]. The RVRR31 strain was obtained only when the transformation mixture was incorporated in soft agar before plating to limit oxygen availability.

\section{Physiological studies}

(i) Growth in optimal laboratory conditions. The growth of the $r r p$ mutants and isogenic wt cells was monitored in MRS rich medium at $30^{\circ} \mathrm{C}$ without shaking. In this medium the final $\mathrm{pH}$ was $4 \cdot 1-4 \cdot 2$. The wt and mutant strains had similar exponential growth rates. However, RVRR31 cells arrested growth earlier, and the final number of cells was one-fifth that of the wt cultures (data not shown). During stationary phase, cell viability was maintained in all cultures for the first $24 \mathrm{~h}$, decreased about twofold after $48 \mathrm{~h}$ and finally reached complete cell death after $65 \mathrm{~h}$ (data not shown).

(ii) Temperature stress. Heat tolerance was measured at two temperatures. At $39^{\circ} \mathrm{C}$ (upper growth temperature limit of L. sakei), mutants RVRR1, RVRR3 and RVRR 48 grew as well as wt cells, whilst RVRR2 stopped growing after $4 \mathrm{~h}$ and RVRR 31 immediately after the temperature shift (Fig. 4a). At $55^{\circ} \mathrm{C}$, the mutants survived as well as the wt (RVRR1 and RVRR2) or better (RVRR3 and RVRR48) during the first $15 \mathrm{~min}$ of exposure, except for RVRR31 in which no surviving cells were found after $30 \mathrm{~min}$ of challenge (Fig. 4b). These results indicate that both Rrp-2 and Rrp-31 are required for bacterial growth at elevated temperature. Inactivation of $r r p-31$ also has a profound effect on susceptibility to heat killing, suggesting that the $r r p-31$ gene is required for heat tolerance.

Cold tolerance was also examined after exposure of cells 

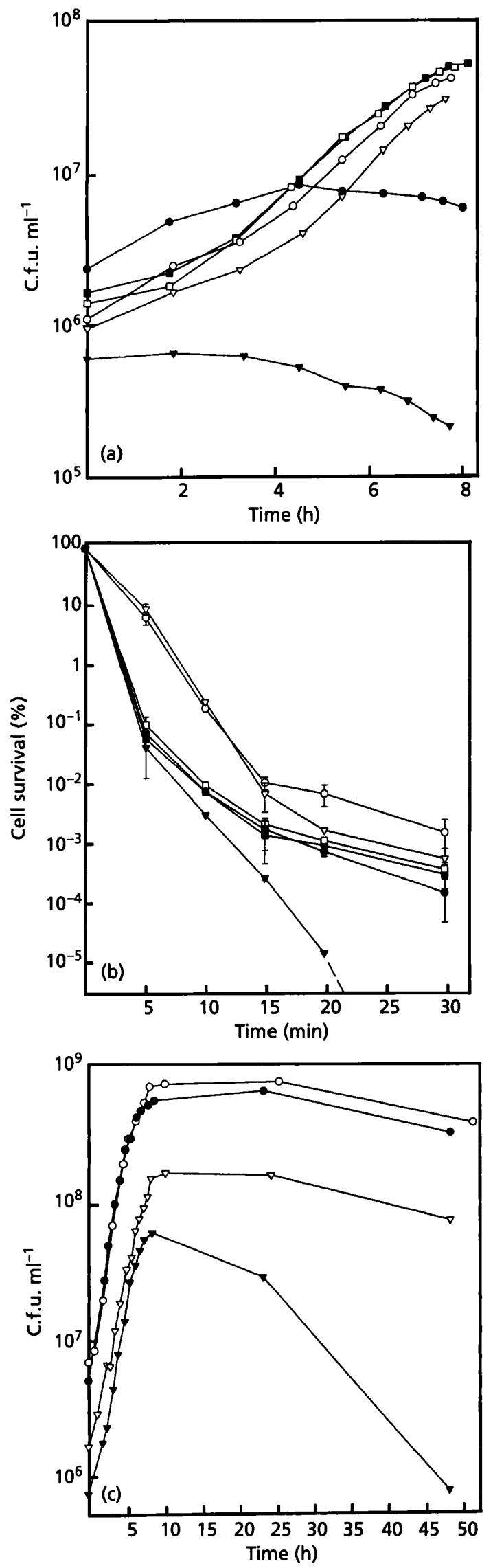

in the early-stationary phase to $4{ }^{\circ} \mathrm{C}$. The mutant and wt cells had a similar cold tolerance since $100 \%$ of cells retained viability for $6 \mathrm{~d}$ after the challenge (data not shown).

(iii) Oxidative stress. Cell counts of wt and mutant strains were compared during growth in MRS medium with and without aeration. In wt cells, the growth rate and yield and survival in stationary phase were independent of aeration (Fig. 4c). Among the rrp mutants, only RVRR31 cells stopped growing early with aeration, and the final number of cells was one-quarter that of nonaerated cultures. Moreover, viability of stationary-phase RVRR31 cells showed a marked decrease (about 100fold) in the aerated culture after $48 \mathrm{~h}$ of growth. These results are consistent with our difficulty in obtaining a RVRR31 strain, which we attribute to the poor aerobic growth of the mutant on solid medium. Thus, although not essential, Rrp-31 is important for optimal growth and stationary-phase survival under aerobic conditions.

Hydrogen peroxide, a by-product of aerobic metabolism, is cytotoxic when in excess due to its reactivity towards proteins, lipids and DNA. As wt $L$. sakei accumulates $\mathrm{H}_{2} \mathrm{O}_{2}$ during aerobic growth (Berthier, 1993), the poor viability of the RVRR31 strain in the presence of oxygen could be due to sensitivity to $\mathrm{H}_{2} \mathrm{O}_{2}$. The relative survival of mutant and wt strains exposed to $2 \mathrm{mM} \mathrm{H} \mathrm{H}_{2} \mathrm{O}_{2}$ for $5 \mathrm{~min}$ was examined (data not shown). The survival of the RVRR31 mutant strain decreased approximately 200 -fold relative to that of the wt strain. Interestingly, two mutants, RVRR2 and RVRR48, survived about 300 -fold better than the wt strain. These results point to an essential role for the $r r p$ 31 gene with respect to protection of $L$. sakei against oxygen-induced toxicity.

(iv) Acid stress. The effect of acid $\mathrm{pH}$ on the growth and viability of $L$. sakei rrp mutants and wt strains was examined. The $w t$, and the RVRR2, RVRR3 and RVRR31 mutants grew normally when plated on a variable pH MRS medium, whereas RVRR1 (about 100fold difference) and, to a lesser extent, RVRR48 (about sixfold) cells were markedly affected (data not shown). Moreover, both RVRR1 and RVRR48 colonies were much smaller relative to the other isogenic strains. The same differences in sensitivity to low $\mathrm{pH}$ were observed when the survival of cells in stationary phase was measured after incubation for various times at $\mathrm{pH} 3.0$ (data not shown).

Fig. 4. Effects of various stresses on growth and survival of wt and rrp mutant strains. ( $a$, b) Effect of temperature. (a) Cell counts after a temperature shift to $39^{\circ} \mathrm{C}$ plotted as a function of time. (b) Cell cultures were subjected to $55^{\circ} \mathrm{C}$ treatment and percentage survival plotted as a function of time. One to three independent challenges were performed for each strain; the means and standard deviations are indicated where available. 口. wt 23K; $\square$, RVRR1; O, RVRR2; O, RVRR3; , RVRR31; $\nabla$, RVRR48. (c) Effect of oxygen. O, $O$, wt strain grown with and without vigorous agitation, respectively; $\nabla, \nabla$, RVRR31 strain grown with and without vigorous agitation, respectively. 
(v) Susceptibility to vancomycin. In Ent. faecium, the VanR/VanS 2CS regulates transcription of the vanHAX operon, which confers resistance to glycopeptide antibiotics such as vancomycin and teicoplanin (Arthur et al., 1992). In view of the fact that Rrp-31/Hpk-31 are similar to the Ent. faecium VanR/VanS (Table 1), we examined susceptibility of $L$. sakei cells to vancomycin.

We found that $L$. sakei $23 \mathrm{~K}$ was susceptible to vancomycin and calculated the MIC of the antibiotic as $50 \mu \mathrm{g} \mathrm{ml}^{-1}$. Interestingly, disruption of the $r r p-31$ gene led to a 15 -fold increase in the vancomycin MIC, whereas it remained unchanged in the other $r r p$ mutants (data not shown). Thus, inactivation of the rrp-31 gene confers resistance to up to $500 \mu \mathrm{g}$ vancomycin $\mathrm{ml}^{-1}$, a phenotype expected in the case of activation of genes encoding enzymes that synthesize the depsipeptide precursors necessary for cell wall assembly in the presence of vancomycin. Similar results have been obtained for the antibiotic teicoplanin (data not shown).

\section{DISCUSSION}

In this paper, we describe five putative new members of bacterial $2 \mathrm{CSs}$ in $L$. sakei $23 \mathrm{~K}$. These are involved in vancomycin susceptibility and/or are part of a protective response against a variety of stresses. Here we report the first molecular and functional analysis of HPK and RR genes in L. sakei. Our results, along with recent reports related to the regulation of the production of class II bacteriocins sakacin A and sakacin P (Axelsson \& Holck, 1995; Eisjink et al., 1996; Huehne et al., 1996) represent the first attempts to understand the possible functions of $2 \mathrm{CSs}$ in this species.

A PCR-based method (Morel-Deville et al., 1997) allowed us to isolate internal fragments of five RRencoding genes from $L$. sakei $23 \mathrm{~K}$, and to determine the complete nucleotide sequence of these genes as well as those encoding their cognate HPKs. Several authors previously reported the PCR-based identification of HPKs (Bayles, 1993; Lee \& Stock, 1996) or RRs (Kaufman \& Nixon, 1996; Wren et al., 1992) from a number of bacteria. Compared to these reports, our results are even more random since a single round of PCR amplification was sufficient to amplify five different RR genes with a high specificity $(94 \%)$ from a limited number of clones analysed, and it is reasonable to envisage that other RR genes could be obtained by screening more clones. In our experiments, the frequency with which a given gene fragment was amplified was clearly biased (see Results). Such bias might result from the $3^{\prime}$-most $\mathrm{G}$ base in primer $\mathrm{DD}$ being inappropriate for annealing, since the $r r p-48$ gene does not encode a D or $\mathrm{E}$ in this position (see Fig. 2). Other reaction conditions relevant to successful annealing of a given oligonucleotide are also likely to have contributed to this bias. Unexpected PCR products (5 out of 82 ) were also isolated. We and others have previously observed these biases and aspecific background which might simply reflect a limitation of the approach (Kaufman \& Nixon, 1996; Morel-Deville et al., 1997; Wren et al., 1992).

The physical arrangements of the five L. sakei $r r p / h p k$ gene pairs are similar to those of many bacterial sensor-regulator genes, i.e. they are located in close proximity, the $h p k$ gene either immediately downstream from its presumed rrp partner or overlapping it. Putative promoter sequences of Gram-positive bacteria, including lactic acid bacteria (Graves \& Rabinowitz, 1986; Kumar et al., 1993; Matern et al., 1994; Rosenberg \& Court, 1979; Sabelnikov et al., 1995), precede each $r r p$ gene (or the ORF that immediately precedes the $r p-2$ gene) (Ross et al., 1993), and in at least two cases potential transcription terminators are present immediately downstream of the $h p k$ gene (Fig. 1, Tables 1,2 ). Although characteristics of promoters have not yet been fully documented for $L$. sakei, and primer extension and regulation analyses have not yet been definitively addressed, it is tempting to speculate that these five sets of signal transducers form operons, and function together in a specific signalling pathway, as demonstrated for a number of cases in Esch. coli and other bacteria (Fleischmann et al., 1995; Mizuno et al., 1996; Mizuno, 1997).

Analysis of the deduced protein products of the five $r r p$ ORFs demonstrated that they strongly resemble transcriptional activators of the OmpR-PhoB subfamily in both the acceptor and DNA binding/transcriptional domains (Pao \& Saier, 1995). On the basis of such high similarity, it is probable that the putative Rrp products are also transcriptional activators, although experimental proof is required to establish their regulatory role.

The five deduced Hpk products exhibit strong structural homology with the members of the EnvZ-NarX family of orthodox HPKs (Stock et al., 1995), although the

Table 2. Putative 2CS promoter sequences

\begin{tabular}{|c|c|}
\hline Systems & Promoter sequences \\
\hline$r r p-1 / h p k-1$ & TTAGCA $\ldots 20 \mathrm{~N} \ldots$ TTTAAT $\ldots 73 \mathrm{~N} \ldots$ ATG $(r r p-1)$ \\
\hline$r r p-2 / h p k-2$ & TAGGCA $\ldots 15 \mathrm{~N} \ldots$ TGCTATACT $\ldots 89 \mathrm{~N} \ldots$ ATG $($ orfC $)$ \\
\hline$r r p-3 / h p k-3$ & TTGAAT $\ldots 17 \mathrm{~N} \ldots$ TATAAT $\ldots 31 \mathrm{~N} \ldots$ ATG $(r r p-3)$ \\
\hline $\operatorname{rrp}-31 / h p k-31$ & TATGTTAAAAT $\ldots .144 \mathrm{~N} \ldots$ ATG $(r r p-31)$ \\
\hline$r r p-48 / h p k-48$ & TTGGTT $\ldots 19 \mathrm{~N} \ldots$ TATAAT $\ldots .23 \mathrm{~N} \ldots$ ATG $(r r p-48)$ \\
\hline
\end{tabular}


whole $h p k-2$ sequence must be determined for a complete comparison. Two hydrophobic membrane-spanning segments predict that each protein consists of two domains: a non-conserved $\mathrm{N}$-terminal extracytoplasmic presumed signal-input (sensor) domain, and a conserved C-terminal intracytoplasmic domain required to transmit the signal further to the regulatory partner through transphosphorylation (Parkinson \& Kofoid, 1992) (Fig. 1).

All these features suggest that the L. sakei $\mathrm{Rrp} / \mathrm{Hpk}$ protein pairs function as signal-transducing proteins via a mechanism of phosphorylation-dephosphorylation similar to those described for the 2CS EnvZ-OmpR (Pao \& Saier, 1995).

The effect of various environmental factors on the five mutant strains in which a rrp gene was disrupted by plasmid insertion was monitored and compared with that on the wt parental strain. We cannot exclude a polar effect of plasmid insertion on the expression of downstream located genes but usually RR genes form operons with genes involved in the same signalling pathway, therefore no function other than that controlled by the 2CS should be affected.

The L. sakei rrp-2 mutant was found to have a temperature-sensitive phenotype compared to the wt. In contrast, the $r r p-3$ and $r r p-48$ mutants survived heat shock well, and showed similar growth kinetics at elevated temperatures. The $r r p-2$ and $r r p-48$ mutants were also much more resistant to oxidative stress. Sequence comparisons and a distance-based phylogenetic tree (data not shown) revealed that these three pairs of $2 \mathrm{CS}$ group with the B. subtilis PhoR-PhoP proteins that regulate the expression of genes involved in phosphate assimilation (Makino et al., 1986a, b). Such relatedness may not necessarily imply that these gene products are also involved, either directly or indirectly, in the signal-transduction mechanism underlying the response to phosphate limitation of $L$. sakei. However, it would be interesting to determine whether subsets of proteins, including alkaline phosphatase, are induced upon growth of wt $L$. sake $i$ in low-phosphate conditions and whether this response is lost in these $r r p$ mutants, as shown in $B$. subtilis wt and phoP strains.

Our results show that the $r r p-1$ gene is essentiel for bacterial growth and acid tolerance. Sequence comparisons revealed that the $\mathrm{Rrp}-1 / \mathrm{Hpk}-1$ protein pair is homologous to the B. subtilis $2 \mathrm{CS} \mathrm{YxdJ} / \mathrm{YxdK}$, the function of which is not yet known (Yoshida et al., 1994). Rrp-1/Hpk-1 encoding and surrounding sequences have common features with $Y x d J / Y x d K$, in particular they both are adjacent to homologous ABC transporter and accessory proteins (Fath \& Kolter, 1993). This is unlikely to be coincidental as the probability that juxtaposition occurred by chance in each species is very low. Hence, this arrangement may reflect some common ancestral organization and/or a common regulatory pathway. Furthermore, in L. sakei the genes encoding the $2 \mathrm{CS}$ proteins and the genes encoding the $A B C$ transporter seem to be transcribed from divergent overlapping promoters, which could be regulatorially linked.

The rrp-31 mutant displays poor growth and viability under normal laboratory conditions and increased susceptibility to heat, acid $\mathrm{pH}$, oxygen and hydrogen peroxide. Moreover, this mutant was difficult to generate in $L$. sakei. This could reflect an inability to withstand some form of stress experienced during transformation. Together, these results suggest the involvement of Rrp-31 in the regulation of a general stress protein, the lack of which in the mutant may have pleiotropic effects. The molecular details of this process and the extent of the physiological consequences of Rrp31 regulation have yet to be ascertained.

Mutation in the rrp-31 gene confers resistance to vancomycin and teicoplanin. The connection of the Rrp-31 mutation to vancomycin resistance is not clear. Glycopeptides such as vancomycin inhibit the final stage of peptidoglycan assembly by binding to the $D$-alanyl-Dalanine (D-Ala-D-Ala) C-terminal residues of cell-wall precursors present on the bacterial cell surface (Reynolds, 1989). In Ent. faecium, inducible resistance to high levels of vancomycin is coupled with the synthesis of modified murein precursors ending in the depsipeptide D-alanine-D-lactate (D-Ala-D-Lac) rather than in D-Ala-D-Ala, which decrease their affinity to glycopeptide antibiotics (Bugg et al., 1991). Modification of peptidoglycan precursors that terminate by D-Ala-D$\mathrm{Lac}$ is a common feature of the intrinsically glycopeptide-resistant lactic acid bacterial species (BillotKlein et al., 1994; Handwerger et al., 1994). The resistance mechanism in these species is the same as that in enterococci with acquired glycopeptide resistance. Therefore, it is probable that vancomycin resistance in the $L$. sakei rrp-31 mutant is associated with the synthesis and incorporation of D-Lac-ending peptidoglycan precursors instead of the usual D-Ala-ending precursor although no experimental results are yet available. D-Lactate is produced during growth of $L$. sakei $23 \mathrm{~K}$ (F. Berthier, personal communication). We are currently investigating whether D-lactate is implicated in the peptidoglycan precursor synthesis in the L. sakei mutant and whether the rrp-31 mutation correlates with an increase or a change in D-lactate production. At this time, one can only speculate that the Rrp-31/Hpk-31 2CS somehow links cell wall biochemistry and general stress response.

Vancomycin and glycopeptides are widely used to treat severe infections by Gram-positive bacteria (Courvalin, 1990). The emergence of glycopeptide resistance in enterococci threatens the efficiency of antimicrobial therapy. In lactic acid bacteria, the mechanism of resistance to glycopeptides has not been systematically investigated, perhaps because these organisms are of little clinical significance. However, the widespread use of vancomycin has led to more frequent recognition of these species as opportunistic pathogens (for a review see Gasser, 1994). This trend, as well as our results showing acquired resistance to vancomycin in L. sakei, 
should renew interest in the mechanism of resistance to glycopeptides.

The role that $L$. sakei $\mathrm{Rrp} / \mathrm{Hpk}$ play in the quality traits of micro-organisms in commercial starter cultures is unknown. Their ability to influence cellular tolerance to antagonistic metabolic products (acids, $\mathrm{H}_{2} \mathrm{O}_{2}$ ) and to physical parameters such as temperature or oxygen suggest they may elicit some regulation with industrial importance. Further studies will be needed to identify precisely which cellular systems they regulate.

\section{ACKNOWLEDGEMENTS}

We are grateful to Era Cassuto and Michel Arthur for critical reading of the manuscript.

\section{REFERENCES}

Alex, L. A. \& Simon, M. I. (1994). Protein histidine kinases and signal transduction in prokaryotes and eukaryotes. Trends Genet 10, 133-139.

Anderson, D. G. \& McKay, L. L. (1983). Simple and rapid method for isolating large plasmid DNA from lactic streptococci. Appl Environ Microbiol 46, 549-552.

Appleby, J. L., Parkinson, J. S. \& Bourret, R. B. (1996). Signal transduction via the multi-step phosphorelay: not necessarily a road less traveled. Cell 86, 845-848.

Arthur, M., Molinas, C. \& Courvalin, P. (1992). The VanS-VanR two-component regulatory system controls synthesis of depsipeptide peptidoglycan precursors in Enterococcus faecium BM4147. J Bacteriol 174, 2582-2591.

Axelsson, L. \& Holck, A. (1995). The genes involved in production and immunity to sakacin $\mathrm{A}$, a bacteriocin from Lactobacillus sake Lb706. J Bacteriol 177, 2125-2137.

Bayles, K. W. (1993). The use of degenerate, sensor gene-specific, oligodeoxyribonucleotide primers to amplify DNA fragments from Staphylococcus aureus. Gene 123, 99-103.

Berthier, F. (1993). On the screening of hydrogen peroxidegenerating lactic acid bacteria. Lett Appl Microbiol 16, 150-153.

Berthier, F., Zagorec, M., Champomier-Vergès, M., Ehrlich, S. D. \& Morel-Deville, F. (1996). Efficient transformation of Lactobacillus sake by electroporation. Microbiology 142, 1273-1279.

Billot-Klein, D., Gutmann, L., Sablé, S., Guittet, E. \& van Heijenoort, J. (1994). Modification of peptidoglycan precursors is a common feature of the low-level vancomycin-resistant VanBtype Enterococcus D366 and the naturally glycopeptide-resistant species Lactobacillus casei, Pediococcus pentosaceus, Leuconostoc mesenteroides, and Enterococcus gallinarum. J Bacteriol 176, 2398-2405.

Bugg, T. D. H., Dutka-Malen, S., Arthur, M., Courvalin, P. \& Walsh, C. T. (1991). Molecular basis for vancomycin resistance in Enterococcus faecium BM4147: biosynthesis of a depsipeptide peptidoglycan precursor by vancomycin resistance proteins $\mathrm{VanH}$ and VanA. Biochemistry 30, 10408-10415.

Chang, C. \& Meyerowitz, E. M. (1994). Eukaryotes have 'twocomponent' signal transducers. Res Microbiol 145, 481-486.

Courvalin, P. (1990). Resistance of enterococci to glycopeptides. Antimicrob Agents Chemother 34, 2291-2296.

Dear, N. \& Staden, R. (1991). A sequence assembly and editing program for efficient management of large projects. Nucleic Acids Res 19, 3907-3911.
Devereux, J., Haeberli, P. \& Smithies, O. (1984). A comprehensive set of sequence analysis programs for the VAX. Nucleic Acids Res $12,387-395$.

Eisjink, V. G. H., Brurberg, M. B., Middelhoven, P. H. \& Nes, I. F. (1996). Induction of bacteriocin production in Lactobacillus sake by a secreted peptide. J Bacteriol 178, 2232-2237.

Fath, M. J. \& Kolter, R. (1993). ABC transporters: bacterial exporters. Microbiol Rev 57, 995-1017.

Fleischmann, R. D., Adams, M. D., White, O. \& 37 other authors (1995). Whole-genome random sequencing and assembly of Haemophilus influenzae RD. Science 269, 496-512.

Gasser, F. (1994). Safety of lactic acid bacteria and their occurrence in human clinical infections. Bull Inst Pasteur 92, 45-67.

Graves, M. C. \& Rabinowitz, J. C. (1986). In vivo and in vitro transcription of the Clostridium pasteurianum ferredoxin gene. Evidence for extended promoter elements in Gram-positive organisms. J Biol Chem 261, 11409-11415.

Hammes, W. P. \& Knauf, H. J. (1994). Starters in the processing of meat products. Meat Sci 36, 155-168.

Handwerger, S., Pucci, M. J., Volk, K. J., Liu, J. \& Lee, M. S. (1994). Vancomycin-resistant Leuconostoc mesenteroides and Lactobacillus casei synthesize cytoplasmic peptidoglycan precursors that terminate in lactate. J Bacteriol 176, 260-264.

Huhne, K., Axelsson, L., Holck, A. \& Kröckel, L. (1996). Analysis of the sakacin P gene cluster from Lactobacillus sake Lb674 and its expression in sakacin-negative L. sake strains. Microbiology 142, 1437-1448.

Kaufman, B. I. \& Nixon, B. T. (1996). Use of PCR to isolate genes encoding $\sigma^{54}$-dependent activators from diverse bacteria. I Bacteriol 178, 3967-3970.

Kumar, A., Malloch, R. A., Fujita, N., Smillie, D. A., Ishihama, A. \& Hayward, R. S. (1993). The minus 35-recognition region of Escherichia coli sigma 70 is inessential for intiation of transcription at an 'extended minus 10 ' promoter. J Mol Biol 232, 406-418.

Lee, P. J. \& Stock, A. M. (1996). Characterization of the genes and proteins a two-component system from the hyperthermophilic bacterium Thermotoga maritima. J Bacteriol 178, 5579-5585.

Leloup, L., Ehrlich, S. D., Zagorec, M. \& Morel-Deville, F. (1997). Single-crossover integration in the Lactobacillus sake chromosome and insertional inactivation of the $p t s I$ and lacL genes. Appl Environ Microbiol 63, 2117-2123.

Makino, K., Shinagawa, H., Amemura, M. \& Nakata, A. (1986a). Nucleotide sequence of the $p h o B$ gene, the positive regulator gene for the phosphate regulon of Escherichia coli K-12. J Mol Biol $190,37-44$.

Makino, K., Shinagawa, H., Amemura, M. \& Nakata, A. (1986b). Nucleotide sequence of the $p h o R$ gene, a regulatory gene for the phosphate regulon of Escherichia coli K-12. J Mol Biol 192, 549-556.

Martinez-Hackert, E. \& Stock, A. M. (1997). The DNA-binding domain of OmpR: crystal structures of a winged helix transcription factor. Structure 5, 109-124.

Matern, H. T., Klein, J. R., Henrich, B. \& Plapp, R. (1994). Determination and comparision of Lactobacillus delbrueckii susbsp. lactis DSM7290 promoter sequences. FEMS Microbiol Lett 122, 121-128.

Mercenier, A., Pouwels, P. H. \& Chassy, B. M. (1994). Genetic engineering of lactobacilli, leuconosctocs and Streptococcus thermophilus. In Genetics and Biotechnology of Lactic Acid Bacteria, pp. 252-283. Edited by M. J. Gasson \& W. M. de Vos. Glasgow: Blackie. 
Mizuno, T. (1997). Compilation of all genes encoding twocomponent phosphotransfer signal transducers in the genome of Escherichia coli. DNA Res 4, 161-168.

Mizuno, T. \& Tanaka, I. (1997). Structure of the DNA-binding domain of the OmpR family of response regulators. $\mathrm{Mol}$ Microbiol 24, 665-670.

Mizuno, T., Kaneko, T. \& Tabata, S. (1996). Compilation of all genes encoding bacterial two-component signal transducers in the genome of the cyanobacterium, Synechocystis sp. strain PCC 6803. DNA Res 3, 407-414.

Morel-Deville, F., Ehrlich, S. D. \& Morel, P. (1997). Identification by PCR of genes encoding multiple response regulators. Microbiology 143, 1513-1520.

Pao, G. M. \& Saier, M. H., Jr (1995). Response regulators of bacterial signal transduction systems: selective domain shuffling during evolution. J Mol Evol 40, 136-154.

Parkinson, J. S. (1993). Signal transduction schemes of bacteria. Cell 73, 857-871.

Parkinson, J. S. \& Kofoid, E. C. (1992). Communication modules in bacterial signalling proteins. Annu Rev Genet 26, 71-112.

Pearson, W. R. \& Lipman, D. J. (1988). Improved tools for biological sequence comparision. Proc Natl Acad Sci USA 85, 2444-2448.

Reynolds, P. E. (1989). Structure, biochemistry and mechanism of action of glycopeptide antibiotics. Eur J Clin Microbiol Infect Dis 8, 943-950.

Rosenberg, M. \& Court, D. (1979). Regulatory sequences involved in the promotion and termination of RNA transcription. Annu Rev Genet 13, 319-353.

Ross, W., Gosink, K. K., Salomon, J., Agarashi, K., Zou, C., Ishihama, A., Severinov, K. \& Gourse, R. L. (1993). A third recognition element in bacterial promoters: DNA binding by the alpha subunit of RNA polymerase. Science 262, 1407-1413.

Rost, B., Casadio, R., Fariselli, P. \& Sander, C. (1995). Transmembrane helices predicted at $95 \%$ accuracy. Protein Sci 4, 521-533.

Sabelnikov, A. G., Greenberg, B. \& Lacks, S. A. (1995). An extended -10 promoter alone directs transcription of the DpnlI operon of Streptococcus pneumoniae. J Mol Biol 250, 144-155.

Sambrook, J., Fritsch, E. F. \& Maniatis, T. (1989). Molecular Cloning: a Laboratory Manual, 2nd edn. Cold Spring Harbor, NY: Cold Spring Harbor Laboratory.

Schillinger, U., Kaya, M. \& Lücke, F. K. (1991). Behaviour of Listeria monocytogenes in meat and its control by a bacteriocin- producing strain of Lactobacillus sake. J Appl Bacteriol 70, 473-478.

Seki, T., Yoshikawa, H., Takahashi, H. \& Saito, H. (1987). Cloning and nucleotide sequence of $p h o P$, the regulatory gene for alkaline phosphatase and phosphodiesterase in Bacillus subtilis. $J$ Bacteriol 169, 2913-2916.

Seki, T., Yoshikawa, H., Takahashi, H. \& Saito, H. (1988). Cloning and nucleotide sequence of the Bacillus subtilis phoR gene. $J$ Bacteriol 170, 5935-5938.

Sorokin, A., Serror, P., Pujic, P., Azevedo, V. \& Ehrlich, S. D. (1995). The Bacillus subtilis chromosome region encoding homologues of the Escherichia coli $m s s A$ and $r p s A$ gene products. Microbiology 141, 311-319.

Stiles, M. E. (1996). Biopreservation by lactic acid bacteria. Antonie Leeuwenhoek 70, 331-345.

Stiles, M. E. \& Hastings, J. J. W. (1991). Bacteriocin production by lactic acid bacteria: potential use in meat preservation. Trends Food Sci Technol 2, 247-251.

Stock, A. M., Mottonen, J. M., Stock, J. B. \& Schutt, C. E. (1989). Three-dimensional structure of CheY, the response regulator of bacterial chemotaxis. Nature 337, 745-749.

Stock, J. B., Surette, M. G., Levit, M. \& Stock, A. M. (1995). Twocomponent signal transduction systems: structure-function relationships and mechanisms of catalysis. In Two-component Signal Transduction, pp. 25-51. Edited by J. A. Hoch \& T. J. Silhavy. Washington, DC: American Society for Microbiology.

Verplaetse, A. (1994). Infuence of raw meat properties and processing technology on aroma quality of raw fermented meat products. In Proceedings of the 40th International Conference of Meat Science and Technology 1994, pp. 45-65. The Hague: Euroscience.

Volz, K. (1995). Structural and functional conservation in response regulators. In Two-component Signal Transduction, pp. 53-64. Edited by J. A. Hoch \& T. J. Silhavy. Washington, DC: American Society for Microbiology.

Wren, B. W., Colby, S. M., Cubberley, R. R. \& Pallen, M. J. (1992). Degenerate PCR primers for the amplification of fragments from genes encoding response regulators from a range of pathogenic bacteria. FEMS Microbiol Lett 78, 287-291.

Yoshida, K., Sano, H., Miwa, Y., Ogasawara, N. \& Fujita, Y. (1994). Cloning and nucleotide sequencing of a $15 \mathrm{~kb}$ region of the Bacillus subtilis genome containing the iol operon. Microbiology 140, 2289-2298.

Received 11 March 1998; revised 16 June 1998; accepted 19 June 1998. 